\title{
Phyllachora graminis, P. silvatica, Epichloe typhina and Acrospermum graminum on grasses in Finland
}

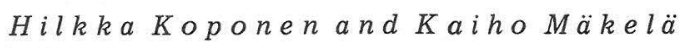

University of Helsinki, Department of Plant Pathology, SF-00710 Helsinki 71, Finland

Present address: H. Koponen, Department of Botany, University of Helsinki, Unioninkatu 44, SF-00170 Helsinki 17, Finland.

K. Mäkelä, Institute of Plant Pathology, Agricultural Research Centre, Box 18, SF-01301 Vantaa 30, Finland.

Abstract. - Material of this study consists of c. 4650 grass samples gathered on leys, field borders, and forests throughout the country during 1966-1974. Collections of Department of Plant Pathology, and Botanical Museum, University of Helsinki, and Mr. Pentti Alanko's herbarium were also examined.

Phyllachora graminis (Pers. ex Fries) Nke. was found on 26 samples of three grass species: Agropyron caninum (L.) PB., A. repens (L.) PB., and Pleum pratense L., being most common on $A$. caninum in South Finland.

P. silvatica Sacc. \& Speg. was found on ten samples of Festuca ovina L., throughout the country.

Epichloë typhina (Pers.) Tul. was found on 96 samples of 15 grass species: Agrostis stolonifera L., A. tenuis Sibth., Anthoxanthum odoratum L., Avena pratensis L., Calamagrostis canescens (Web.) Roth, C. epigeios (L.) Roth, C. lapponica (Wg.) Hartm., C. neglecta (Ehrh.) G., M. \& Sch., C. purpurea Trin., Dactylis glomerata L., Festuca rubra L., Phleum Boehmeri Wib., P. pratense L., and Poa pratensis L., throughout the country, being most common on Dactylis glomerata and Phleum pratense in Ahvenanmaa and South Finland, besides on Calamagrostis species in North Finland.

Acrospermum graminum Lib. was found on 28 specimens of eight grass species: Agropyron repens, Calamagrostis epegeios, Dactylis glomerata, Deschampsia caespitosa (L.) PB., Festuca rubra, F. ovina, and Phleum pratense in southern Finland, being most common on A. repens.

All these fungi were found to be rare or accidental and infrequent, usually on wild grasses on field borders, and forests. All the fungi are of negligible importance.

\section{Material and Methods}

This study is based on c. 4650 grass samples gathered throughout the country on leys, field borders, and forests. In Finland numerous wild grasses are common throughout the country (HULTÉN 1971). Besides several grass specimens were examined in collections of Department of Plant Pathology, HPP, Botanical Museum, University of Helsinki, $\mathrm{H}$, and Mr. Pentti Alanko's herbarium.

Abbreviations of the Finnish biological provinces are in accordance with HEIK INHEIMO and RAATIKAINEN (1971).

Collectors were Pentti Alanko = P.A., Hilk- ka Koponen = H.K., Jorma Kurtto = J.K., and Kaiho Mäkelä = K.M.

Microscopic slides were prepared from all the samples bearing symptoms of the fungi. The slides were preserved in lactic-acid and lactophenol solution, where the fungi were also measured and photographed. The microphotographs were taken by Kaiho Mäkelä.

\section{Results and Discussion}

Phyllachora graminis (Pers. ex Fries) Nke. in Fuckel Symb. Myc. 216, 1869, syn. cf. ORTON 1944: 46, ARX and MÜLLER 1954: 215, PARBER Y 1967: 286. 
Phyllachora is a genus of Sphaeriales (ARX and MÚLLER 1962, AINSWORTH 1967).

$P$. graminis causes tar spot on various grass species. It is widespread in Europe, Canada and the United States (ORTON 1944, SPRAGUE 1950, MUNK 1957, PARBERY 1967, DENNIS 1968). In Scandinavia the species is common on Agropyron species (JøR STAD 1945, ERIKSSON 1967b).

In Finland the present authors have reexamined some older specimens of $P$. graminis in the collections of $\mathrm{H}$ and HPP. They found this fungus on two unidentified grasses gathered by P. A. Karsten in $1860 \mathrm{EH}$ : Messukylä. The fungus has been known since 1873 (KARSTEN Fung. Fenn. no. 483) on unidentified grass as the name Hypopteris graminis.

This species has often been mistaken for a Telimenella gangraena (Fr.) Petr., and Scirrhia agrostidis (Fuck.) Wint. (cf. JøRSTAD 1945, ERIKSSON 1967b), as well as for a Puccinia actaeae-agropyri Ed. Fischer (ILMA VIRTA 1973).

In this study, $P$. graminis was found rather rare and infrequent in the southern parts of the country (Fig. 1). The fungus was most common on Agropyron caninum (L.) PB. About 46 per cent of the specimens studied (28 specimens) were infected by the fungus. $P$. graminis was also found on $A$. repens (L.) PB. (six of 230 specimens studied), and on Phleum pratense L. (one of 545 specimens). The fungus has been also found common on the same Agropyron species in southern Fennoscandia (cf. JøRSTAD 1945, ERIKSSON 1967b). It is also known on Phleum pratense in the USA (ORTON 1944). Most of the specimens of $A$. caninum were collected in August (3. IV. - 25. X.) and those of $A$. repens in September (8. VI. - 27. X.).

$P$. graminis was found to be of rare. and infrequent occurrence on wild grasses, on borders of fields, and swards of yards (cf. JøRSTAD 1945, SPRAGUE 1950).

$P$. graminis causes on the leaves of grasses dark brown to black, elliptical to linear pseudostromata, in size on $A$. caninum (0.5) 2.9 (11.5) x (0.5) $0.8(1.0) \mathrm{mm}$ and on $A$. repens (1.0) $4.2(11.0) \times(0.5) 0.9(2.0) \mathrm{mm}$ (Fig. 2) (cf. OR TON 1944, PARBERY 1967). The size of perithecia, asci and ascospores were of the following kind. A. caninum perithecia (128) $145 \times 178(210) \mu \mathrm{m}$, asci (38) $70.2(90) \times(6) 8.2(10) \mu \mathrm{m}$, ascospores (7) $10.6(14) \times(3.5) 5.6(8) \mu \mathrm{m} ;$ A. repens perithe-

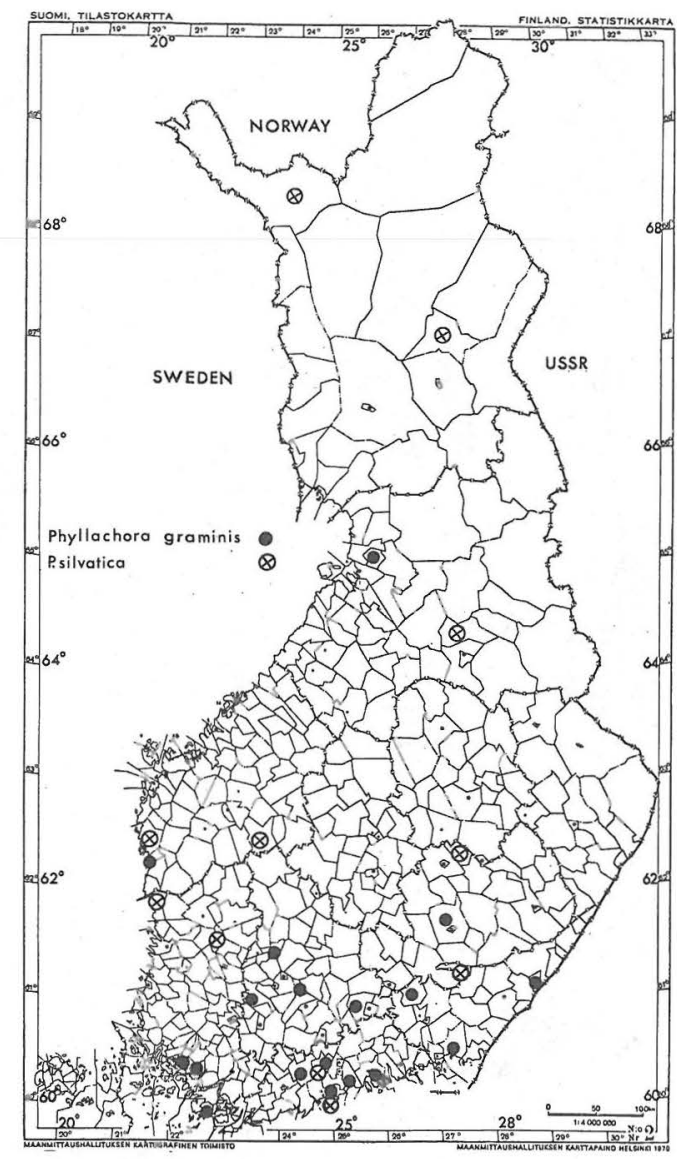

Fig. 1. The origin of Phyllachora graminis and $P$. silvatica on grasses in Finland.

cia (120) $219 \times 241$ (450) $\mu \mathrm{m}$, asci (46) 73.5 (110) x (6) $7.9(10) \mu \mathrm{m}$, ascospores (6) 10.5 (16) $\mathrm{x}$ (4) $5.6(7) \mu \mathrm{m}$, and Phleum pratense perithecia $197 \times 295$, asci (76) 81.2 (88) x (6) $6.7(7.2) \mu \mathrm{m}$, ascospores (8) 10.8 (14) $\mathrm{x}$ (4.2) 5.1 (6) $\mu \mathrm{m}$ (Figs. 2 and 3). In the present study the size of the fungus is rather similar than reported by KARSTEN (1873), WINTER (1887), SAMPSON and WESTERN (1942), ORTON (1944), and PARBERY (1967).

Examined material

\section{On Agropyron caninum:}

V: Vihti 19. VIII. 1934 (J. I. Liro, H); U: Helsinki 3. IV. 1972 (H.K.), Helsinki commune 25.X. 1969 (P.A.), Nurmijärvi 23. VI. 1973 (H.K.), Sipoo 28. VIII. 1969 (P.A.), Vantaa 31. VIII. 1927 (V. Heikinheimo \& J. I. Liro, H); EK: Hamina 31. VII. 1934 (V. Krohn, H); EH: Lammi IX. 1973 (V. Ilmavirta, H), Urjala 15. X. 1972 (P.A.); ES: Imatra 28. VIII. 1934 (V. Lehtola, H), Mikkeli commune 12. IV. 1974 (H.K.); EP: Kristiinankaupunki 19. VIII. 1972 

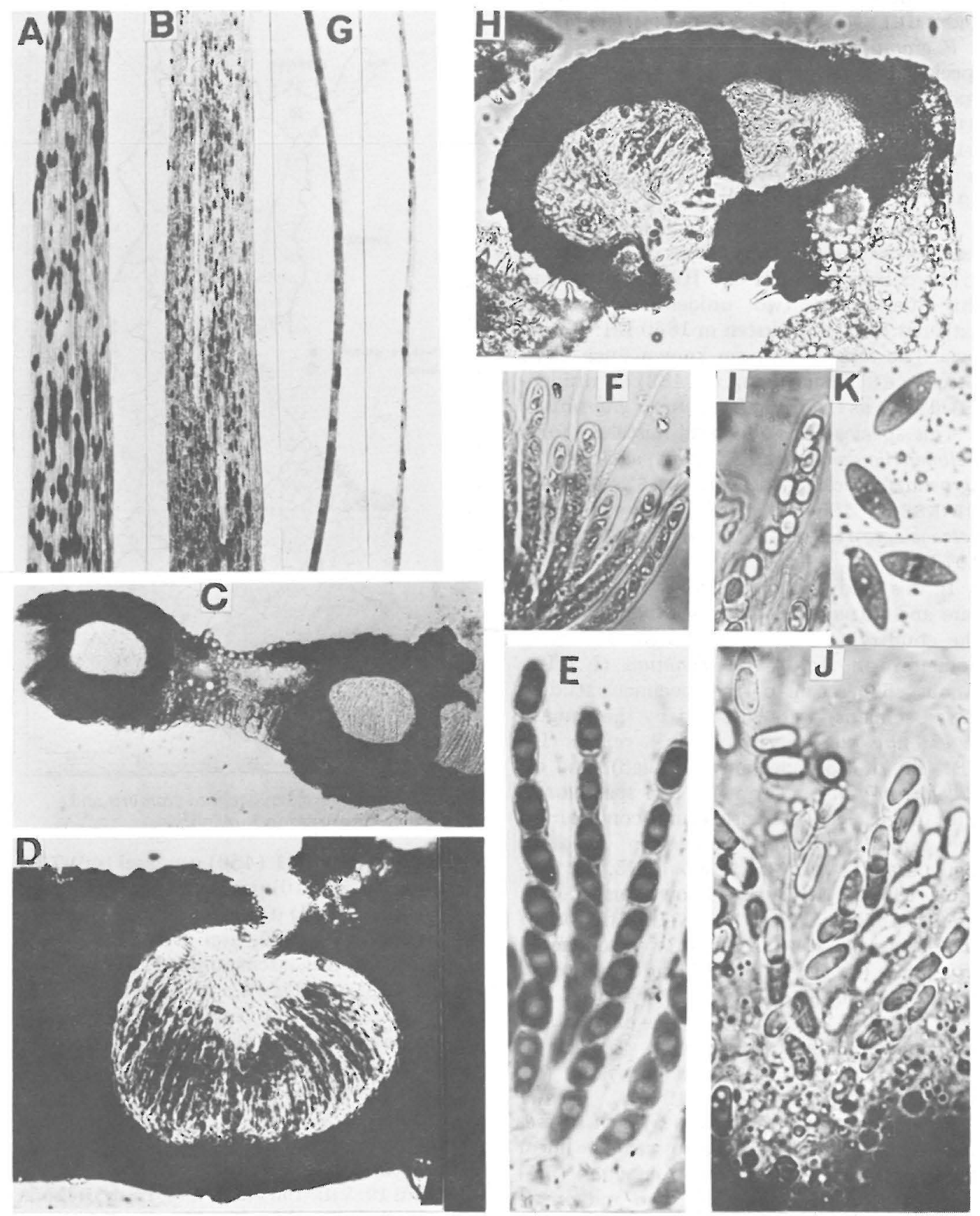

Fig. 2. Phyllachora graminis A-F. A, C, E: on Agropyron repens Piikkiö 18. IX. 1919, B, D, F: on A. caninum, B: Kristiinankaupunki 19. VIII. 1972, D, F: Helsinki 3: IV. 1972. P. silvatica on Festuca ovina G, H-K. G, I, J: Paltamo 9. VIII. 1973, H: Merikarvia 14. VIII. 1972 , K: Närpiö 19. VIII. 1972, C, D, H: section of leaf with pseudostroma and perithecia, E, F, J-K: asci and ascospores. A, B, G: x 1, C: x 100, D: x 300, H: x 200, F: x 500, I, J: x 800, $\mathrm{E}, \mathrm{K}: \mathrm{x} 1000$. 
(H.K.); PP: Kiiminki IX. 1961 (T. Ulvinen, H).

On Agropyron repens:

V: Piikkiö 18. IX. 1919 (J. I. Liro), Turku 25. IX. 1934 (L.E. Kari, H), 1960 (P.A., H), Västanfjärd 18. IX. 1959 (L. \& H. Roivainen, H), 8. VI. 1974 (H.K.); U: Helsinki 27. X. 1974 (H.K.), Porvoo commune, 16. VIII. 1936 (W. Nyberg, H); EH: Hollola 10. VIII. 1968 (P.A.), Jaala 9. X. 1971 (P. Ilonoja), Tyrväntö 8. IX. 1965 (P.A., H), Urjala 15. X. 1972 (P.A.).

On Phleum pratense:

U: Helsinki commune 24. V. 1934 (V. Brummer).

On unidentified grasses: EH: Messukylä IX. 1860, 5. X. 1860 (P. A. Karsten, H).

Additions (localities not included in the maps): Unidentified grasses: U: Porvoo IX. 1928 (W. Nyberg, H), Porvoo commune XII. 1936 (W. Nyberg, $\mathrm{H})$.

Phyllachora silvatica Sacc. \& Speg. in Saccardo, p. 410, 1878, syn. P. sylvatica Sacc. \& Sp. Mich. I: 410, cf. SACCARDO 1883: 603; syn. cf. ORTON 1944: 46, PARBERY 1967: 346 .

P. silvatica causes tar spot, especially on Festuca species. It is widespread throughout Europe, America and Australasia (GUYOT 1932, SAMPSON and WESTERN 1942, SPRAGUE 1950, PARBERY 1967). In Scandinavia the species is probably common on Festuca ovina L. and it occurs also on F. rubra L. (ERIKSSON 1967b).

In Finland the fungus has been known since 1925 on $F$. ovina gathered by Kari in EnL: Enontekiö (13. VII. TUR) (K A RI 1936).

In the present study $P$. silvatica was found on Festuca ovina throughout the country (Fig. 1). About 10 per cent of the specimens studied (106 specimens) were infected by the fungus. It was found to be uncommon and infrequent on wild grasses in forests (cf. SPRAGUE 1950). Most of the specimens were collected in August (28. VI. - 16. X.).

$P$. silvatica causes on the leaves of $F$. ovina small black spots (pseudostromata) (Fig. 2). The size of perithecia was (190) $290(340) \mu \mathrm{m}$ in diam., asci (60) 71.0 (84) x (10) 12 (14) $\mu \mathrm{m}$, and ascospores (10) 16.2 (21.6) x (5) 6.4 (10) $\mu \mathrm{m}$ (Figs. 2 and 3). In the present study the size of the fungus is rather similar than reported by ORTON (1944) and PARBERY (1967).

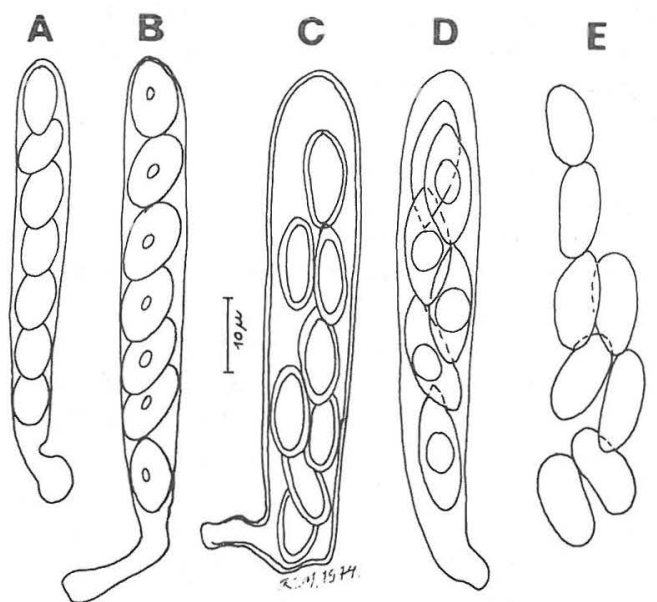

Fig. 3. Asci and ascospores. A, B: Phyllachora graminis, A: on Agropyron repens Piikkiö 18.IX.1919, B: on Phleum pratense Helsinki commune 24. V. 1934. C-E: $P$. silvatica on Festuca ovina, C: Jäppilä 3. VII. 1973, D: Pelkosenniemi 7. VIII. 1973, E: Paltamo 9. VIII. 1973.

\section{Examined material}

On Festuca ovina:

U: Nurmijärvi 19. VIII. 1973 (H.K.); St: Merikarvia 14. VIII. 1972 (H.K.), Suodenniemi 21. VIII. 1972 (H.K.); ES: Suomenniemi 28. VI. 1972 (H.K.); EP: Alavus 16. X. 1966 (P.A., H), Närpiö 19. VIII. 1972 (H.K.); PS: Jäppilä 3. VII. 1973 (H.K.); Kn: Paltamo 9. VIII. 1973 (H.K.); KemL: Pelkosenniemi 7. VIII. 1973 (H.K.); EnL: Kaaresuvanto 27. VII. 1973 (H.K.).

Epichloë typhina (Pers.) Tul. Ann. Sc. Nat. Bot. IV, 13: 18, 1860, syn. cf. KARSTEN 1873: 204, WINTER 1887: 145, conidial stage Sphacelia typhina (Pers.) Sacc. Michelia 2: 297, 1881, syn. cf. LIN DAU 1910: 459.

Epichlo $\ddot{e}$ is a genus of Hypocreales (ARX and M ÜLLER 1954, AINSWORTH 1967).

E. typhina causes choke disease on a large number of grasses. It is widespread in Europe and North America, and is found in East Asia (SPRAGUE 1950, DENNIS 1968, MÜHLE and FRAUENSTEIN 1970, KOHLMEYER and KOHLMEYER 1974). In Europe especially Dactylis glomerata L. and Phleum pratense L. are infected by $E$. typhina. The economic importance of the disease lies in the damage to crops grown primarily for seed production (SAMPSON and WESTERN 1942, KIRBY 1958, KASK 1962，MÜHLE and FRAUENSTEIN 1970). In Scandinavia the fungus is rather common on Dactylis glomerata and Phleum pratense, on others it has been found only a few times (LIND 1913, 
JøRSTAD 1945, ERIKSSON 1967a). It has been known since the 1820's in Sweden (cf. ERIKSSON 1967a) and since the 1840's in Norway (cf. JOR ST AD 1945).

In Finland the earliest specimen of $E$. typhina has been found on an unidentified grass (in $\mathrm{H}$ and HPP), gathered by P.A. Karsten 1860. The fungus has been known since 1873 (KARSTEN Fung. Fenn., no. 164) on Phleum pratense as Cordyceps typhina Fr. According to KARSTEN (1873) the fungus has been found on Phleum pratense and Dactylis glomerata here and there in Finland (cf. LIR O 1934 Myc. Fenn. no. 286). The fungus has been also found on Poa pratensis L. (LIR 1939 Myc. Fenn. no. 589).

In Lapland the fungus has been found only on Calamagrostis lapponica (Wg.) Hartm. and C. purpurea Trin. (cf. LIR O 1934, 1939, Myc. Fenn. no. 287 and 590).

In the present study E. typhina occurred on 96 grass samples of 15 grass species, mostly in the southern parts of the country (Fig. 4). In North Finland there are only a few observations of the fungus on Calamagrostis species (C. lapponica, C. neglecta Ehrh., G., M. \& Sch., C. purpurea) (cf. LIR O 1934, 1939). It is also the same in northern Scandinavia (cf. ERIKSSON 1967a). The fungus was most common on Dactylis glomerata and Phleum pratense, about 3 per cent of the samples studied, as usually in Europe (cf. JØR STAD 1945, KIRBY 1958，1961，KASK 1962, ERIKSSON 1967a, MÜHLE and FRAUENSTEIN 1970). On the other hand E. typhina was found rare on Agrostis tenuis Sibth. and only occasionally on Poa pratensis, besides on older specimens of Agrostis stolonifera L., Anthoxanthum odoratum L., Avena pratensis L., Calamagrostis canescens (Web.) Roth, C. epigeios (L.) Roth, Festuca rubra L., and Phleum Boehmeri Wib. Chiefly the same hosts have been found in Scandinavia (cf. JøRSTAD 1945, ERIKSSON 1967a). The fungus was usually found on wild grasses on field borders, and only rare on cultivated leys. The fungus was found mostly in July (5. VI 2. X).

Epichloë typhina has occurred infrequent in Finland (BRUMMER 1937). In summer 1974, the fungus was found exceptionally abundant on two timothy stands (four and seven years old), which were for seed production (EH: Kärkölä). The number of diseased plants were $7-14$ per $\mathrm{m}^{2}$ in seven years old stand. The reason for epidemical occurrence of the fungus may be the old stands and the exceptionally rainy summer 1974 (cf. HAY . REN 1903, SAMPSON and WESTERN 1942, LARGE 1954, MÜHLE and FRAUENSTEIN 1970).

The fungus causes cream-coloured, later yellow-dark orange stromata, surrounding sheats or culms of living grasses. The stroma bears numerous, immersed, densely covered perithecia with elongate asci and filiform ascospores (Fig. 5). In the present study the length of stromata varied $0.5-8.0 \mathrm{~cm}$ according to hosts (cf. KARSTEN 1873).

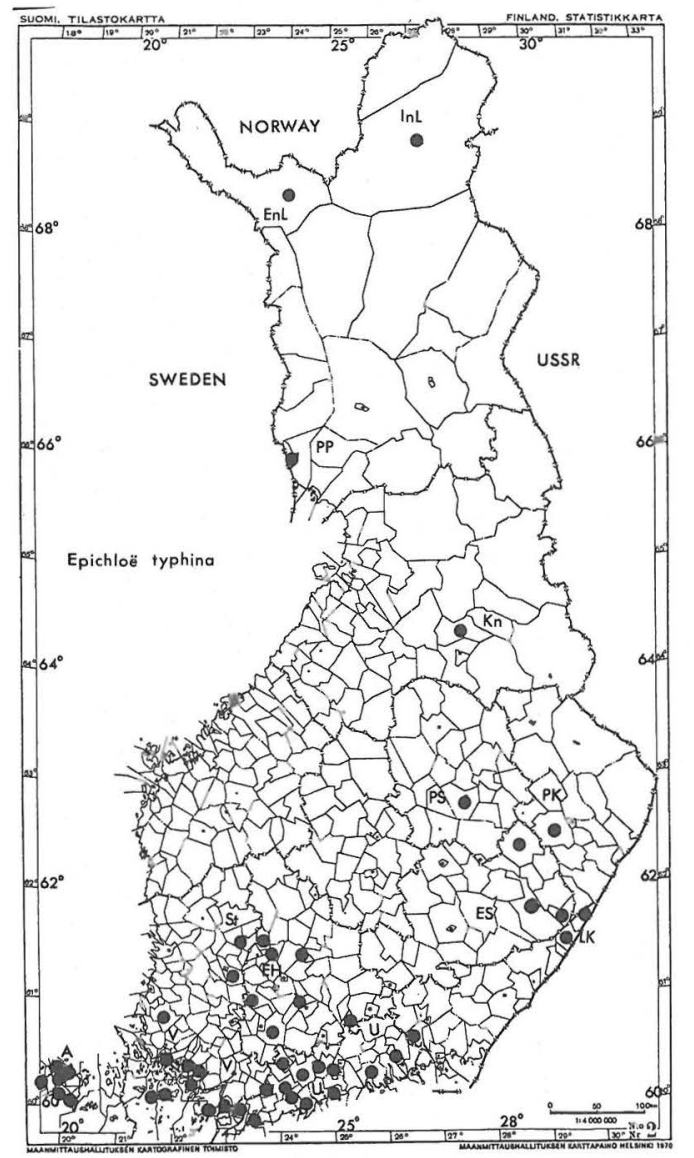

Fig. 4. The origin of Epichloë typhina on grasses in Finland.

\section{Examined material}

On Agrostis stolonifera:

EH: Lepaa 22. VIII. 1944 (Irja Karaila, H).

On A. tenuis:

A: Geta 23. VII. 1967 (P.A.), Lemland 20. VII. 1912 (T. J. Hintikka), 9. VII. 1938 (J. I. Liro \& H. Roivainen, H); V: Karjalohja 27. VII. 1970 (P.A.), Tenhola 2. X. 1965 (P.A.); EH: Hattula 2. X. 1965 

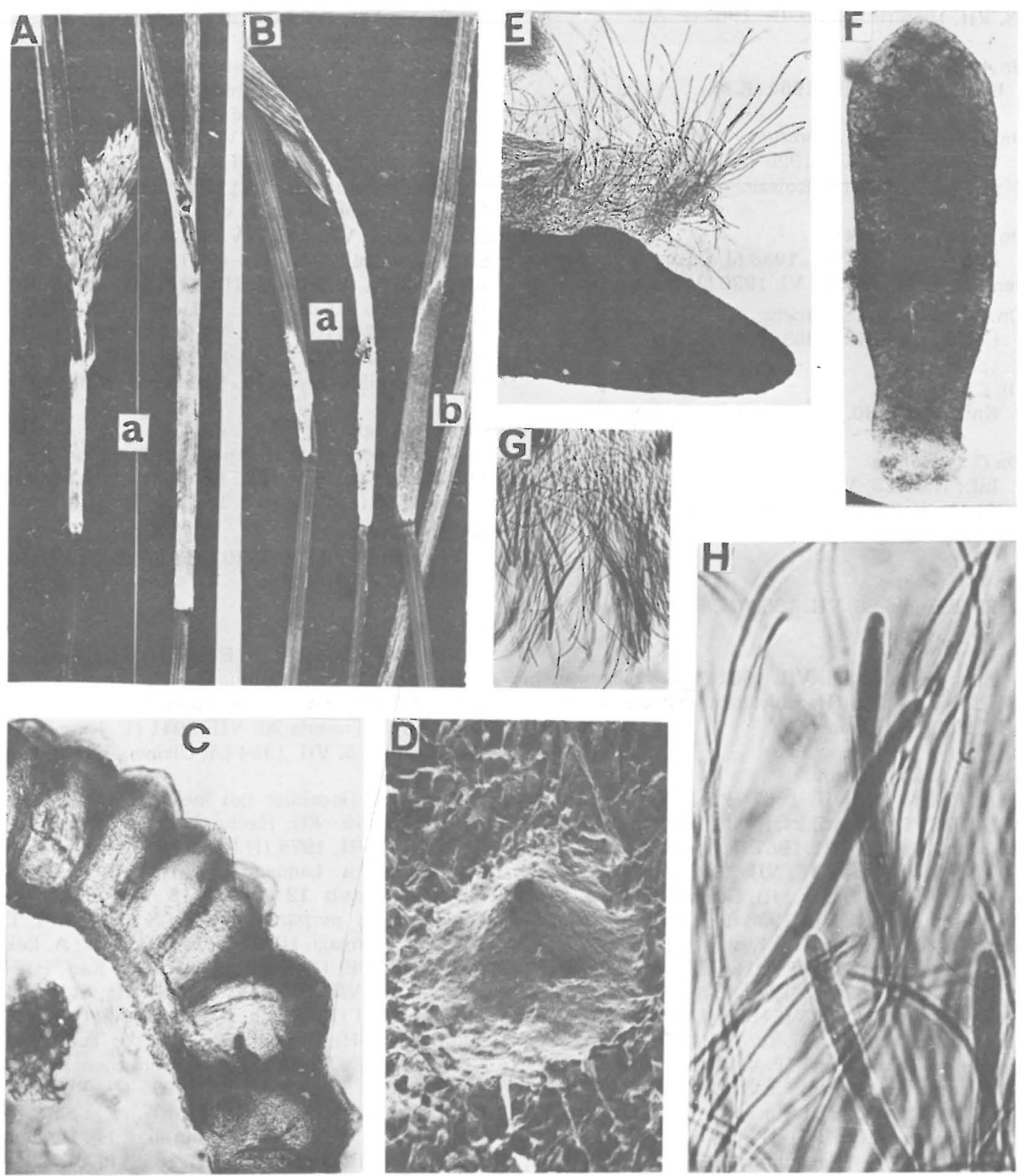

Fig. 5. Epichloë typhina A-D. A, D: on Dactylis glomerata and B, C: on Phleum pratense Helsinki 1. VIII. 1974, A, D, B a: conidial stage, B b: perithecial stage. Acrospermum graminum E-H. E: on Dactylis glomerata Fagervik 24. V. 1972, F: on Agropyron repens Pielavesi 30. VI. 1971, G, H: on Calamagrost is arundinacea Vantaa 28. V. 1972. E, F: fruit body with asci, G, H: asci and ascospores. A, B: x 1, C: x 300, D: x 1000, SEM, Viikki, E: x 100, F: x 70, G: x 250, H: x 1300 . 
(P.A., H), Tyrväntö (Hattula) 16. IX. 1965 (P.A.), 28. VII. 1965 (P.A.), 30. IX. 1965 (P.A.).

On Agrostis sp.:

U: Helsinki 3. VIII. 1954 (K.M.).

On Anthoxanthum odoratum:

V. Piikkiö 21. VI. 1920 (J. I. Liro, H), Västanfjärd 15. VI. 1968 (H. Roivainen, H).

On Avena pratensis:

A: Lemland 13. VII. 1938 (J. I. Liro \& H. Roivainen, H); V: Piikkiö 21. VI. 1920 (J. I. Liro, H).

On Calamagrostis canescens:

U. Tuusula 8. IX. 1968 (P.A.).

On C. epigeios:

Kn: Paltamo 30. VIII. 1960 (T. Ulvinen, H).

\section{On C. lapponica:}

InL: Ivalo 23. VII. 1928 (J. Eränen, H), 20. VII. 1931 (V. Heikinheimo, H), 21. VII. 1931 (J. I. Liro \& V. Heikinheimo, H).

On C. neglecta:

PP: Karunki 26. VII. 1968 (H. Roivainen, H).

On C. purpurea:

EnL: Lätäseno 25. VII. 1961 (L. \& H. Roivainen, H), 24. VII. 1966 (H. Roivainen, H); InL: Ivalo 24. VI. 1974 (M. Koponen).

On Dactylis glomerata:

A: Eckerö 24. VII. 1967 (P.A., H), Finström 2. VII. 1912 (T. J. Hintikka, H), 11. VII. 1912 (V. Heikinheimo, H), 22. VII. 1967 (P.A., H), Geta 23. VII. 1967 (P.A.), Jomala 18. VII. 1938 (J. I. Liro \& al., H), 24. VII. 1967 (P.A., H), Lemland 19. VII. 1912 (V. Pesola, H), 10. VII. 1938 (J. I. Liro \& H. Roivainen, H), 16. VII. 1963 (H. Luther, H), 25. VII. 1967 (P.A., H), Saltvik 10. VII. 1912 (V. Heikinheimo, H); V: Karjalohja 26. VII. 1970 (P.A.), 31. VIII. 1974 (P.A.), Kakskerta 30. VI. 1935 (L. Kari, H); U: Helsinki 6. IX. 1967 (P.A.), 23. VII. 1974 (H.K.), Kirkkonummi 2. VII. 1967 (P.A.), Porvoo 14. VI. 1917 (Ch. Boldt, H), Siuntio 15. VII. 1967 (P.A.), Tammisaari 10. VIII. 1962 (H. Roivainen, H); EH: Tyrväntö (Hattula) 8. VIII. 1971 (P.A.); ES: Punkaharju 9. VIII. 1974 (P.A.), Savonlinna 10. VIII. 1974 (P.A.); LK: Parikkala 10. VIII. 1974 (P.A.), Uukuniemi 29. VI. 1972 (H.K.); PS: Heinävesi 5. VII. 1972 (H.K.), Kuopio 11. VII. 1947 (R. Ruotsalo, H).

On Festuca rubra:

A: Finström 2. VII. 1912 (T. J. Hintikka, H).

On Phleum Boehmeri:

A. Finström 6. VII. 1912 (V. Heikinheimo, H), 14. VII. 1912 (V. Pesola, H); St: Hämeenkyrö VII. 1910 (J. S. W. Koponen, H).

On $P$. pratense:

V: Laitila 25. VII. 1972 (J.K.), Lohja 30. VI.
1913 (Ch. Boldt, H), Nauvo 24. VII. 1972 (J.K.), Pusula 18. VII. 1972 (J.K.), Uskela 3. VII. 1919 (E. Häyrén, H), Vihti 3. VII. 1919 (J. I. Lir̄o, H), 15. VIII. 1968 (K.M.), Västanfjärd 20. VI. 1960 (Laila \& H. Roivainen, H); U: Elimäki 23.VII. 1974 (P.A.), 28. VII. 1974 (P.A.), Helsinki 14. VII. 1972 (H.K.), 2. VIII. 1972 (H.K.), 23. VII. 1974 (H.K.), Kirkkonummi 14. VII. 1974 (H.K.), Liljendal 11. VIII. 1928 (V. Heikinheimo \& al., H), Tammisaari 26. VII. 1902 (E. Häyrén, H), 26. VII. 1906 (E. Häyrén, H), Tikkurila 12. VII. 1928 (V. Heikinheimo \& al., H); St: Tyrvää 14. VII. 1916 (V. Heikinheimo, H), 2. VII. 1960 (L. Roivainen, H); EH: Kärkölä 15. VIII. 1974 (H.K.), Sahalahti 24. VII. 1972 (K.M.), Urjala 16. VII. 1972 (P.A.), 10. VIII. 1972 (H.K.), 1972 (P.A.), 14. VII. 1973 (P.A.), Ylöjärvi 16. VIII. 1971 (P. Ilonoja); PK: Liperi 11. VIII. 1973 (K.M.).

\section{On Phleum sp:}

A: Korppoo 20. VII. 1943 (A. Wegelius, H); V: Lohja 10. VII. 1892 (Ch. Boldt, H); EH: Mustiala 7. VII. 1865 (P.A. Karsten, H).

On Poa pratensis:

V: Parainen 10. VI. 1910 (K. Linkola, H); U: Helsinki 3. VIII. 1972 (H.K.).

On unidentified grasses:

V: Finby VII. 1920 (F. Elfing, H), Merimasku 18. VIII. 1860 (P. A. Karsten, H); U: Tammisaari 26. VII. 1902 (E. Häyrén, H), Tikkurila 19. VII. 1912 (J. I. Liro), Tuusula 26. VII. 1941 (E. Häyrén, H); EH: Tampere 5. VII. 1954 (A. Ulvinen, H).

Additions (localities not included in the maps): Agrostis tenuis: EH: Hauho 15. VII. 1975 (H.K.), Lammi 11. VII. 1975 (H.K.), 12. VII. 1975 (H.K.). Agrostis sp.: A. Lemland 19. VII: 1912 (V. Pesola, H); EH. Hattula 12. VII. 1916 (H. Raneken, H). Calamagrostis purpurea: KemL: Sodankylä 6. IX. 1972 (H. Harmaja, H). Dactylis glomerata: A. Eckerö 6. IX. 1949 (I. Kukkonen \& L. E. Kari, H); U: Helsinki 19. VII. 1958 (V. Erkamo, H); St. Karkku 16. VII. 1961 (K. Vanne, H); EH: Tyrväntö 19. VII. 1965 (P.A., H). Phleum pratense: U. Tuusula 27. VII. 1941, (E. Häyrén, H); St. Huittinen 13. VIII. 1975 (H.K.), Tyrvää 29. VI. 1965 (H. Roivainen, H); EH: Lammi 12. VII. 1975 (H.K.). Poa pratensis: U. Helsinki 3. V. 1949 (T. Rautavaara, H). Unidentified grass: EH: Tammela 29.VII. 1865 (P. A. Karsten, $\mathrm{H})$.

Except where indicated, all specimens are preserved in HPP, Alanko's specimens are in his private herbarium.

Acrospermum graminum Lib. Fl. crypt. Ard. I: 33, 1830 (cf. SACCAR DO 1883: 807). The fungus has been regarded as a mere variety of $A$. compressum Tode ex Fries. (cf. 
WEBSTER 1956, ERIKSSON 1967a). WEBSTER (1956) presented that they are two separate species on the basis of their perfect and conidial stages. Acrospermum has been referred to several very disparate orders (cf. WEBSTER 1956, ERIKSSON 1967a). According to AINSWORTH (1967) it is a genus of Dothideales. A conidial state belongs to Moniliales (WEBSTER 1956).

ERIKSSON (1967: 385) divides A. graminum into two varieties $A$. graminum var. graminum and $A$. graminum var. decipiens (Pass. in Rab.) O. Erikss. according to fruitbodies.

A. graminum is typical graminicolous fungus with club-shaped fruit-bodies (WEBSTER 1956). It occurs in Europe and in North America (SACCARDo 1883). In Fennoscandia the fungus is also rather common on numerous grass species (ERIKSSON 1967a).

In Finland the authors re-examined some old specimens in $\mathrm{H}$ and found $A$. graminum on two unidentified grasses in 1865 and 1866, collected by P. A. Karsten. According to KARSTEN (1873:247) the fungus is common on culms of grasses in spring.

In this study the fungus was found on 25 specimens of eight grass species in the southern parts of the country (Fig. 6.) The fungus was most common on Agropyron repens, about 7 per cent of the samples studied (230 samples) were infected by the fungus. Besides the fungus was found on occasion on Calamagrostis arundinacea, C. epigeios, Dactylis glomerata, Deschampsia caespitosa, Festuca rubra, F. ovina and Phleum pratense. Chiefly the same hosts have been found in Scandinavia (ERIKSSON 1967a). The fungus was found mostly on dead overwintered culms on grasses in May - July (9. IV - 6. VII).

The fruit-bodies of $A$. graminum (Fig. 5) were club-shaped (0.4) 0.8 (1.2) $\mathrm{mm}$ high and (225) 315-370 (490) $\mu \mathrm{m}$ wide, dark brown in colour, single or in groups, seated on a broader base and bursting through the epidermis of culm, rounded or pointed at the apex. Asci: fasciculate, narrowly cylindrical, tapering at the base, (200) 330 (490) $\mu \mathrm{m}$ long, (4.3) 5.3 (6.0) $\mu \mathrm{m}$ wide, separated by filiform paraphyses. Ascospores filiform, hyanile, about as long as the asci, 0.5-1.0 $\mu \mathrm{m}$ wide (Fig. 5) (cf. SACCARDO 1883, WEBSTER 1956). In the present study the size of the fungus is rather similar than reported by WEBSTER (1956).

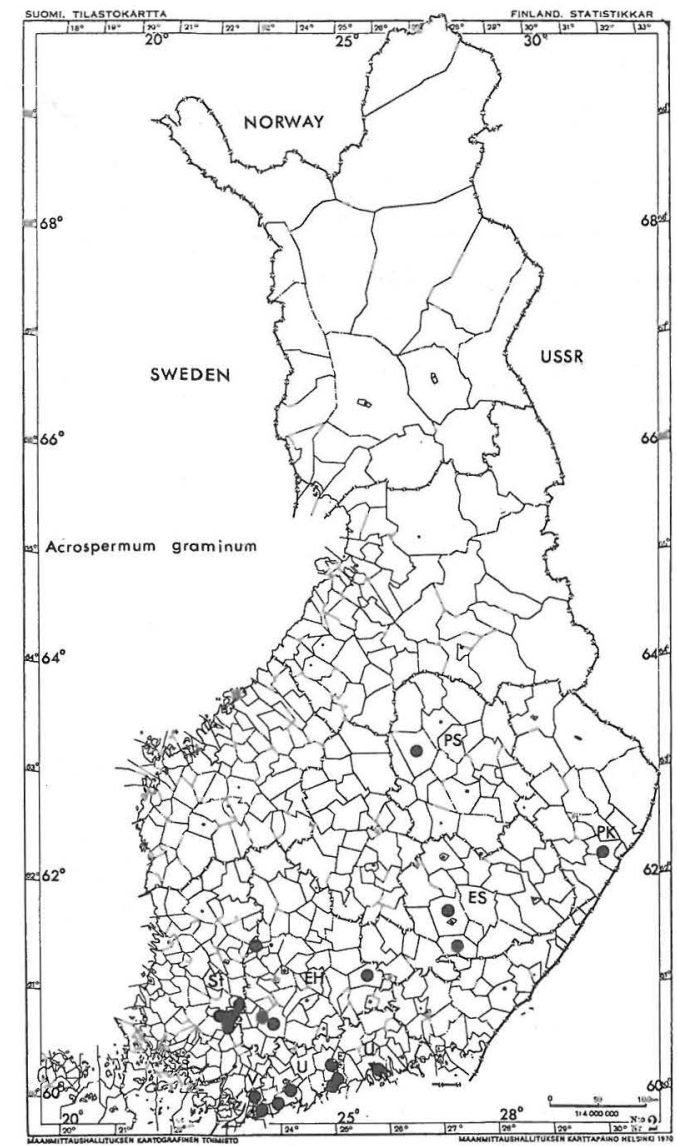

Fig. 6. The origin of Acrospermum graminum on grasses in Finland.

The authors found the condial stage of $A$. graminum in one samples of Agropyron repens in U: Vantaa 28. V. 1972.

A. graminum is of negligible importance.

\section{Examined material}

On Agropyron repens:

V: Pohja 8. V. 1973 (H.K.); U: Helsinki 23. V. 1969 (P.A.), 9. IV. 1972 (H.K.), Porvoo commune 12. VI. 1974 (H.K.), Siuntio 8.V. 1973 (H.K.), Snappertuna 24. V. 1972 (K.M.), Vantaa 28. V. 1972 (H.K.); St: Loimaa 1. VI. 1972 (J. Kurtto), Loimaa commune 10. V. 1973 (H.K.), Mellilä 1. VI. 1972 (J. Kurtto), Metsämaa 1. VI. 1972 (J. Kurtto); EH: Asikkala 15. VI. 1972 (J. Kurtto), Forssa 1.VI. 1972 (J. Kurtto), Tammela 1. VI. 1972 (J. Kurtto); PS: Pielavesi 30. V. 1971 (H.K.); PK: Tohmajärvi 30.VI. 1972 (H.K.). 
On Calamagrostis arundinacea:

U: Vantaa 28. V. 1972 (H.K.).

On Calamagrostis epigeios:

U: Tuusula 8. VI. 1972 (K.M.), 28. IV. 1974 (H.K.).

On Dactylis glomerata:

V: Inkoo 24. V. 1972 (K.M.); ES: Mikkeli commune 13. IV. 1974 (H.K.).

On Deschampsia caespitosa:

V: Inkoo 8. V. 1973 (H.K.), Snappertuna 8. V. 1973 (H.K.).

On Festuca ovina:

EH: Nokia 16. V. 1872 (V. Heikinheimo, H).
On F. rubra:

ES: Ristiina 6. VII. 1972 (H.K.).

On Phleum pratense:

V: Pohja 8. V. 1973 (H.K.).

On unidentified grasses:

V: Merimasku 13. V. 1865 (P. A. Karsten, H); EH: Mustiala 15. IV. 1866 (P.A. Karsten, H).

Acknowledgements. The authors express their sincere thanks to Mrs. Sirpa Palojärvi, Mc. S., and Miss Ritva Kauppinen for their technical assistance, and Mr. Pentti Heinänen, who made photographs.

\section{REFERENCES}

A INSWORTH, G. C. 1967: Ainsworth \& Bisby's Dictionary of the fungi. - $547 \mathrm{pp}$. Kew Surrey.

ARX, J. A. von \& MÜLLER, E. 1954: Die Gattung der amerosporen Pyrenomyceten. -- Beitr. Krypt.-Flora Schweiz 11, 1: 1-434.

BRUMMER, V. 1937: Beobachtungen uiber die in Finnland auf dem Timothee auftretenden Pilzkrankheiten. - J. Sci. Agric. Soc. Finl. 9: 165-180.

DENNIS, R. W. G. 1968: British Ascomycetes. $455 \mathrm{pp}$. Stuttgart.

ERIKSSON, O. 1967a: On graminicolous Pyrenomycetes from Fennoscandia. 2. Phragmosporous and scolecosporous species. - Arkiv Bot. 6: 381-440.

- 1967b: On graminicolous Pyrenomycetes from Fennoscandia. 3. Amerosporous and didymosporous species. - Arkiv Bot. 6: 441466.

G UY OT, A.L. 1932: Observations sur la distribution géographique comparée de quelques espèces végétales et de certains de leurs parasites naturels. ( $2^{\mathrm{e}}$ Note). Sur quelques champignons parasites des Graminées. - Rev. Path. Vég. Entomolog. Agric. 19, 2: 36-47. (Ref. Rev. Appl. Mycol. 11: 721-722).

H ÄYREN, E. 1903: Epichloë typhina (Pers.) Tul. tuhokasvina. - Luonnon Ystävä 7: 163-164.

HEIKINHEIMO, O. \& RAATIKAINEN, M. 1971: The recording of localities of biological finds in Finland. - Ann. Entomolog. Fenn. 37, 1a: $1-27$.

HULTÉN, E. 1971: Atlas of the distribution of vascular plants in northwestern Europe. $531 \mathrm{pp}$. Stockholm.

ILMAVIRTA, V. 1973: On the macroecology of rustfungi (Uredinales) in Lammi commune southern Finland. - Ann. Bot. Fennici 10:
JØRSTAD, I. 1945: Parasitsoppene pá kultur-og nyttevekster i Norge. - Meld. Stat. Plantepatol. Inst. 1. $142 \mathrm{pp}$. Oslo.

KARI, L. E. 1936: Micromyceten aus FinnischLappland. - Ann. Bot. Soc. Vanamo 8, 3: 125.

KARsten, P. A. 1873: Mycologia Fennica. II. Pyrenomycetes. - Bidr. Känned. Finl. Nat. Folk. 23. $251 \mathrm{pp}$. Helsingfors.

KASK, K. 1962: (A short survey of fungus diseases of cereal grasses of the Estonia S.S.R.) Botanicheskie issledovaniya (Scripta botanica) II. Rabotȳ po milko- i likhenflore Pribaltiki. Inst. Zool. Bot. Akad. Nauk Estonia S.S.R., Tartu, pp. 163-169.

KIRBY, E. J. M. 1958: Choke of grasses. - Rep. School Agric. Univ. Nottigham 1957, 43-47.

- 1961: Host-parasite relations in the choke disease of grasses. - Trans. Brit. Mycol. Soc. 44: 493-503.

KOHLMEYER, J. 1956: Beobachtungen über die Lebensweise von Epichloë typhina (Pers.) Tul. - Ber. Deutsche Bot. Ges. 69: 149-157.

- \& KOHLMEYER, E. 1974: Distribution of Epichoë typhina (Ascomycetes) and its parasitic fly. - Mycologia 66: 77-86.

LARGE, E. C. 1954: Survey for choke (Epichloë typhina) in cocksfoot seed crops 1951-53. - Plant Pathol. 3: 6-11.

LIND, J. 1913: Danish fungi as represented in the herbarium of E. Rostrup. - 64.8 pp. Copenhagen.

LIN D A U, G. 1910: Fungi imperfecti. in Rabenhorst's Kryptogamen-Flora, Ed. 2. 1, 9.-983 pp. Leipzig.

LIR O, J. I. 1934: Mycotheca Fennica. Die Etiketten N:o 1-300. - 97 pp. Helsinki.

- 1939: Mycotheca Fennica. Die Etiketten N:o 301-600. - 136 pp. Helsinki. 
MUhle, E. \& FRAUENStein, K. 1970: Beobachtungen zum Auftreten des Erstickungsschimmels, Epichloë typhina (Pers.) Tul. an Futtergräsern. - Zeitsch. Pflanzenkrankh. (Pflanzenpath.) Pflanzenschutz 77: 177-185.

MUNK, A. 1957: Danish Pyrenomycetes. - Dansk Bot. Arkiv 17, 1:1-491.

ORTON, C. R. 1944: Graminicolous species of Phyllachora in North America. - Mycologia 36: 18-53.

PARBERY, D. G. 1967: Studies on graminicolous species of Phyllachora Nke. in Fckl. - Aust. J. Bot. 15: 271-375.
SACCARDO, P. A. 1883: Sylloge Fungorum II. 813 pp. Patavii.

SAMPSON, K. \& WESTERN, J. H. 1942: Diseases of British grasses and herbage legumes. 85 pp. Cambrigde.

SPRAGUE, R. 1950: Diseases of cereals and grasses in North America. - 538 pp. New York.

WEBSTER, J. 1956: Conidia of Acrospermum compressum and A. graminum. - Trans. Brit. Mycol. Soc. 39: 361-366.

WINTER, G. 1887: Ascomyceten: Gymnoasceen und Pyrenomyceten. In Rabenhorst's Kryptogamen-Flora, Ed. 2. 1, 2.-928 pp. Leipzig.

Received 1. 11. 1974. 